\title{
МЕТОДОЛОГІЧНІ ОСНОВИ ВИКОРИСТАННЯ ТЕСТОВИХ ЗАВДАНЬ ТА МІСЦЕ І РОЛЬ ТЕСТОВОГО КОНТРОЛЮ У СТРУКТУРІ ВИКЛАДАННЯ НОРМАТИВНОЇ ДИСЦИПЛІНИ “ГІГІЄНА ТА ЕКОЛОГІЯ"
}

\author{
В. Г. Бардов ${ }^{1}$, І. В. Сергета ${ }^{2}$, А. М. Гринзовський ${ }^{1}$ \\ ${ }^{1}$ Національний медичний університет імені О. О. Богомольия, \\ ${ }^{2}$ Вінницький національний медичний університет імені М. І. Пирогова
}

\section{METHODOLOGICAL FOUNDATIONS OF USE OF TESTS AND PLACE AND ROLE OF TEST CONTROL IN THE STRUCTURE OF TEACHING OF NORMATIVE SUBJECT "HYGIENE AND ECOLOGY"}

\author{
V. H. Bardov ${ }^{1}$, I. V. Serheta ${ }^{2}$, A. M. Hrynzovskyi ${ }^{1}$ \\ ${ }^{1}$ National Medical University by O. O. Bohomolets, \\ ${ }^{2}$ Vinnytsia National Medical University by M. I. Pyrohov
}

\begin{abstract}
У статті обгрунтовані методологічні основи та визначені прикладні напрямки використання тестового контролю у структурі навчальної підготовки студентів під час вивчення нормативної дисципліни "Гігісна та екологія".

The article adduces the methodological fundamentals and determines the directions of the applied test control in the structure of educational training of students during the leaming of normative discipline "Hygiene and Ecology".
\end{abstract}

Вступ. Стратегічна мета модернізації медичної освіти в контексті запровадження Свропейської кредитно-трансферної системи полягає у підвищенні конкурентоспроможності української медичної школи на підставі ії входження до єдиного загальноєвропейського простору вищої освіти та єдиного загальноєвропейського простору наукових досліджень $[3,6]$.

Саме тому головним постулатом організації навчального процесу у контексті вимог Болонської конвенції $€$ цілісне та чітко продумане наукове забезпечення навчального процесу на тлі суттєвого збільшення обсягу самостійної роботи студентів шляхом використання сучасних методів організації пізнавальної діяльності і, передусім, використання професійноорієнтованих тестових методик та запровадження методів об' єктивізації контролю знань, що можуть ефективно використовуватися для проведення студентами самоконтролю підготовки до практичних занять і підсумкового модульного контролю, стати структурним елементом дистанційного навчання тощо $[1,2,3,6]$.

Основна частина. Як провідні сфери використання тестового контролю у структурі навчальної підготовки студентів необхідно відзначити:
- проведення поточного контролю знань в ході аудиторних практичних занять;

- здійснення підсумкового модульного контролю;

- удосконалення організації самостійної роботи студентів.

Отже, методологічні основи використання тестових завдань у структурі викладання навчальних дисциплін повинні передбачати реалізацію таких методичних аспектів, як:

- академічний аспект: формулювання тестових питань має стимулювати інтелектуальну діяльність та розвивати пізнавальну активність студентів;

- аналітичний аспект: тестові питання повинні бути спрямовані на виявлення здатності студентів до аналізу інформації та іiі аргументованого відбору;

- прагматичний аспект: тестові завдання мають відбивати пріоритетні питання навчального процесу та професійної практики, а також відображувати ціннісні орієнтації і установки студентів;

- творчий аспект: постановка тестових питань повинна надавати простір для вибірково-пізнавальної діяльності студентів, можливості визначення та відстоювання власної точки зору на проблемну ситуацію, що має місце;

() В. Г. Бардов, І. В. Сергета, А. М. Гринзовський 
- прогностичний аспект: тестові завдання мають сприяти розвитку творчого мислення, моделювати ситуації майбутньої професійної діяльності тощо.

Таким чином, використання тестових методик для оцінки результатів навчальної діяльності студентів надає можливість здійснювати розв'язання питань як діагностичного (оцінка рівня знань, а також визначення того, що ще слід вивчити та допрацювати), так і управлінського (яким чином у подальшому слід керувати процесом навчання та самонавчання) змісту.

Тестові методики оцінки можуть застосовуватися на етапі професійної орієнтаиї та вступу до вищцого навчального закладу з метою встановлення рівня відповідності психофізіологічних якостей і особливостей особистості абітурієнтів вимогам професіограм, психофізіограм та психограм основних медичних спеціальностей.

Проте головною сферою використання тестових методик $€$ їх широке застосування в ході організації навчального прочесу у медичних вищих навчальних закладах, в тому числі під час викладання нормативної дисципліни “Гігієна та екологія” для виявлення рівня опанування теоретичних питань 3 навчальних предметів, які на засадах міжкафедральної інтеграції пов’язані з дисципліною, що вивчається, оцінки рівня вихідних знань та умінь безпосередньо за навчальним предметом, встановлення ступеня засвоєння окремих розділів нормативної дисципліни, визначення ступеня ефективності самостійної роботи студентів, модернізації процесів навчання та самонавчання студентів, організації рубіжного та підсумкового модульного контролю, проведення предметних екзаменаційних випробувань, організації ліцензійних іспитів “ККрок-1”, “Крок-2”, “Крок-3”.

Таким чином, основне місце у діяльності викладача займає застосування різноманітних тестів усniшності, які являють собою сукупність тестових стандартизованих завдань, що використовуються як діагностичний інструментарій для оцінювання певного рівня навчальних досягнень.

До числа головних критерії розроблення та застосування тестів успішності необхідно віднести: надійність, що визначає ступінь відтворення результатів у разі проведення повторних тестувань, валідність, яка характеризує ступінь відповідності методики тестування рівню опанованих студентами навчальних навичок, точність, що дозволяє оцінити межу коливань діапазону правильних відповідей, об'$\epsilon \kappa m u в н і с т ь$, яка визначає надзвичайно низький рівень впливу на результат тестування суб'єктивних чинників та максимально мінімізує їх дію.
Натомість як основні переваги використання mестів успішності потрібно відзначити: уніфікацію та стандартизацію оцінки рівня знань, можливість протягом обмеженого часу охопити контролем велику кількість студентів, можливість проведення не лише вибіркового, але й узагальненого контролю ступеня засвоєння навчального матеріалу, а також високу ефективність у разі проведення систематичного (етапного) очунювання рівня теоретичних знань та практичних навичок, що набуті.

Отже, тести успішності, які використовуються, не $\epsilon$ якимось окремим та однобічним явищем. Насамперед, вони мають ураховувати основні рівні пізнавальної активності студентів, що мають бути досягнуті та надавати можливість виділити тести успішності чотирьох рівнів засвоєння:

Тести успішності I рівня засвоєння являють собою сукупність тестових стандартизованих завдань, що використовуються як діагностичний інструментарій для оцінки певного рівня навчальних досягнень та визначають знання на рівні загальних уявлень $\mathrm{i}$ загальної орієнтації студентів, забезпечуючи проведення контролю на рівні розпізнавання раніше почутого або прочитаного, загальних уявлень про зміст навчальної дисципліни тощо. Їх головною ознакою $є$ визначення переліку відповідей, виходячи зі своїх уявлень, або вибір однієї правильної відповіді з декількох запропонованих відповідей і, отже, основною сферою використання - оцінка вихідного рівня знань.

Тести успішності II рівня засвоєння становлять сукупність тестових стандартизованих завдань, що дозволяють оцінити точність, глибину та повноту теоретичних знань і практичних навичок, а також якість їх відтворення, визначаючи репродуктивні теоретичні і практичні знання, які свідомо відтворюються та застосовуються студентом на рівні типових задач. Такі тести (тестові методики зі множинним вибором відповіді, тестові методики з відповіддю, яка самостійно конструюється, тестові методики, що передбачають визначення правильної послідовності дій під час виконання певного завдання, тестові методики, які зумовлюють знаходження оптимальних співвідношень між окремими рядами даних) дозволяють оцінити точність, глибину та повноту теоретичних знань і практичних навичок студентів, що засвоєні, та якість їх відтворення. Їх головною ознакою $\epsilon$ можливість виявлення здатності студентів використовувати набуті знання, уміння та навички у ході навчального процесу i, отже, основною сферою використання - оцінка ступеня засвоєння окремих розділів навчальної дисципліни, визначення рівня ефек- 
тивності самостійної роботи студентів, удосконалення подальшого керування процесами навчання та самонавчання студентів, проведення рубіжного, підсумкового та екзаменаційного контролю.

Тести успішності III рівня засвоєння являють собою сукупність тестових стандартизованих завдань, що дозволяють оцінити здатність студентів проводити порівняльний диференційований практичнозначущий аналіз різноманітних груп ознак за різними критеріями та визначають рівень професійно-значущих професійних умінь і навичок, що набуті. Їх головною ознакою (тестові методики, які засновані на використанні класифікаційного відбору, тестові методики, що передбачають інтегральну оцінку теоретичної і практичної підготовки студентів) є можливість виявлення здатності студентів використовувати набуті знання, уміння та навички у практично-значущих ситуаціях i, отже, основною сферою використання - проведення рубіжного, підсумкового та екзаменаційного контролю, визначення рівня ефективності самостійної роботи студентів, удосконалення подальшого керування процесами навчання та самонавчання студентів.

Тести успішності IV рівня засвоєння становлять сукупність тестових стандартизованих завдань, що дозволяють виявити ступінь готовності студентів до здійснення творчої діяльності, можливостей розв'язання нестандартних ситуацій у повсякденній навчальній або практичній (професійній) діяльності.

Необхідно відзначити, що основними методами поточного контролю знань студентів, який має бути здійснений під час оцінки рівня засвоєння окремих тем практичного курсу будь-якої навчальної дисципліни, є довільні та стандартизовані методи.

Довільні методи поточного контролю знань студентів зумовлюють: використання усного опитування, застосування письмових методів опитування, розв'язання типових ситуаційних задач, проведення навчально-значущих лабораторних та інструментальних досліджень.

Водночас стандартизовані методи поточного контролю знань студентів, а саме на запровадженні таких підходів наголошують основні засади кредитно-модульної системи організації навчального процесу, мають передбачати: використання структурованих тестових завдань (тести успішності I, II, III та, в окремих випадках, IV рівнів засвоєння), запровадження структурованих ситуаційних завдань, що зумовлюють виконання дій, властивих для практичної діяльності лікаря, застосування структурованих письмових робіт, використання структурованого за процедурою виконання контролю рівня засвоєння практичних навичок, в умовах, які максимально наближені до реальних умов.

Сфера використання стандартизованих методів контролю знань студентів є досить широкою: контроль теоретичної підготовки, контроль рівня засвоєння практичних навичок, контроль рівня засвоєння окремих професійних умінь тощо.

Як головні стандартизовані методи проведення контролю теоретичної підготовки слід відзначити: застосування структурованих письмових робіт, запровадження типових структурованих ситуаційних завдань, використання структурованих тестових завдань (тести успішності I, II та III рівнів засвоєння).

Основними стандартизованими методами проведення контролю рівня засвоєння практичних навичок мають стати: індивідуальний контроль виконання типових практичних навичок та оцінка умінь щодо прикладної інтерпретації одержаних результатів, застосування структурованих письмових робіт щодо визначення нормативних показників, які визначаються під час проведення практичних дій, використання структурованих тестових завдань (тести успішності I, II та III рівнів засвоєння).

Зрештою, як найбільш доцільні та практично-значущі стандартизовані методи проведення контролю рівня засвоєння професійних умінь мають бути визначені: запровадження типових структурованих ситуаційних завдань, що зумовлюють виконання дій, властивих для практичної діяльності лікаря, використання структурованих тестових завдань (тести успішності III та, в окремих випадках, IV рівнів засвоєння).

Отже, будь-який метод стандартизованої оцінки як рівня засвоєння предмета в ході практичних занять, так і під час проведення підсумкового модульного контролю обов' язково передбачає використання тестового контролю.

Тому, розглядаючи особливості використання тестових завдань у структурі викладання предмета "Гігієна та екологія", необхідно зазначити, що такий підхід повинен мати за мету:

- проведення контролю теоретичної підготовки;

- проведення контролю рівня засвоєння теоретичних умінь та практичних навичок;

- проведення контролю рівня засвоєння професійних умінь.

I, отже, саме цей факт зумовлює потребу у розробленні, визначенні адекватності і валідності та подальшому застосуванні тестових завдань, що забезпечують здійснення відповідно вихідного, проміжного та кінцевого контролю знань студентів. 
Виходячи із вищенаведеного, як головні напрямки використання тестового контролю у ході викладання предмета "Гігієна та екологія" передусім, під час проведення практичних занять необхідно відзначити їх застосування як невід'ємного елементу:

- вихідного контролю рівня знань 3 навчальних предметів, які на засадах міжкафедральної інтеграції пов’язані з дисципліною;

- проміжного контролю рівня знань студентів (тести успішності I та II (оцінка точності, глибини та повноти засвоєння теоретичних знань і практичних навичок) рівня засвоєння окремих тем та розділів дисципліни);

- кінцевого контролю рівня знань студентів (тести успішності II та III (оцінка певного рівня професійних умінь) рівня засвоєння окремих розділів та всієї нормативної дисципліни.

Ураховуючи наведені положення, розроблений навчальний посібник "Гігієна і екологія: стандартизовані завдання для тестового контролю”, зміст якого максимально наближений до змісту базового підручника "Гігієна та екологія", а його структура передбачає розгляд та висвітлення наступних розділів $[4,5,7]$ :

Передмова.

Розділ 1. Методологічні основи використання тестових завдань. Місце та роль тестового контролю у структурі викладання нормативної дисципліни "Г Гігієна та екологія.

Розділ 2. Тестові завдання з розділу “Загальні питання гігієни".

Розділ 3. Тестові завдання з розділу “Комунальна гігієна".

Розділ 4. Тестові завдання з розділу "Гігієна харчування".

Розділ 5. Тестові завдання з розділу “Гігієна праці".

Розділ 6. Тестові завдання з розділу “Гігієна дітей і підлітків".

Розділ 7. Тестові завдання з розділу “Гігієна лікувально-профілактичних закладів".

Розділ 8. Тестові завдання з розділу "Радіаційна гігієна".

Розділ 9. Тестові завдання з розділу “Особиста гігієна та психогігієна".

Розділ 10. Тестові завдання з розділу "Гігієна при екстремальних ситуаціях з курсом військової гігієни”.

Розділ 11. Тестові завдання з розділу “Гігієна жарких та тропічних країн”.

Структура викладення основних матеріалів $у$ навчальному посібнику передбачає подання тестових завдань у такій формі:

Назва теми

\section{1. Навчальна мета}

2. Вихідні знання та вміння

3. Питання для самостійної підготовки

4. Лimepamypa

5. Питання тестового контролю (у форматі А*, $\mathrm{B}, \mathrm{C}, \mathrm{D}, \mathrm{E})$

Джерело (а) літератури:

Як основні варіанти подання запитань, а загалом у навчальному посібнику наведено 3250 тестових завдань, слід відзначити 4 наступних варіанти.

Перший варіант - прості (односкладові) запитання. Наприклад:

Назвіть основну мету гісієни:

А. *Збереження та зміцнення здоров'я людини

В. Вивчення стану навколишнього середовища

C. Вивчення етіології та патогенезу захворювань

D. Обгрунтування гігієнічних нормативів та критеріїв здоров'я людини

Е. Прогнозування санітарної ситуації на перспективу

Джерело інформації: Гігієна та екологія / [В. Г. Бардов, В. Ф. Москаленко, С. Т. Омельчук та ін.] ; за ред. В. Г. Бардова. - Вінниця : Нова Книга, 2006. - С. 19.

Другий варіант - складні (багатоскладові) запитання. Наприклад:

Назвіть фактори навколичнього середовища, щзо впливають на здоров'я людини:

А. *Фізичні, хімічні, біологічні, психологічні

В. Колективні, індивідуальні, особистісні

C. Генетичні, фенотипічні

D. Глобальні, популяційні, регіональні, індивідуальні

Е. Психологічні, психофізіологічні, фізіологічні

Джерело інформаціï: Загальна гігієна : пропедевтика гігієни / [Є. Г. Гончарук, Ю. І. Кундієв, В. Г. Бардов та ін.] ; за ред. С. Г. Гончарука. - К. : Вища школа, 1995. - С. 15-16.

Третій варіант - запитання від протилежного. Наприклад:

Назвіть, який принции не відноситься до принциипів гігіснічного нормування:

А. *Принцип абсолютності ГДК

В. Принцип відносності ГДК

С. Принцип розподілу об'єктів санітарної безпеки

D. Принцип першочерговості медичних показань

Е. Принцип диференціації біологічних відповідей

Джерело інформащіï: Загальна гігієна : пропедевтика гігієни / [Є. Г. Гончарук, Ю. І. Кундієв, В. Г. Бардов та ін.] ; за ред. С. Г. Гончарука. - К. : Вища школа, 1995. - С. 138-142.

I, зрештою, четвертий варіант - запитання контентного (узагальненого) змісту. Наприклад: 


\section{ВДОСКОНАЛЕННЯ ВИЩОЇ МЕДИЧНОЇ ОСВІТИ}

Назвіть провідні різновиди санітарії:
А. *Bсе перераховане
В. Шкільна санітарія
С. Житлово-комунальна санітарія
D. Виробнича санітарія
Е. Харчова санітарія

Джерело інформації: Гігієна та екологія / [В. Г. Бардов, В. Ф. Москаленко, С. Т. Омельчук та ін.] ; за ред. В. Г. Бардова. - Вінниця : Нова Книга, 2006. - С. 19.

Результати використання розроблених тестових

\section{Лiтература}

1. Булах І. Є. Проблеми оцінювання знань студентів в контексті Болонської декларації / І. С. Булах, О. П. Волосовець, М. Р. Мруга // Нові напрямки впровадження кредитно-модульної системи організації навчального процесу у вищих медичних і фармацевтичному навчальних закладах України III-IV рівнів акредитації. - Тернопіль, 2011.-С. 12-13.

2. Попередні підсумки запровадження кредитно-модульної системи організації навчального процесу у вищих медичних навчальних закладах та шляхи подальшого удосконалення його організації / В. В. Вороненко, О. П. Волосовець, Ю. С. П'ятницький [та ін.] // Медична освіта. - 2012.№ 2. - С. 18-22.

3. Про завдання з впровадження Європейських стандартів та директив із внутрішньої та зовнішньої гарантії якості в систему підготовки лікарів і провізорів у Національному медичному університеті імені О. О. Богомольця / В. Ф. Москаленко, О. П. Яворовський [та ін.] // Нові напрямки впровадження кредитно-модульної системи орга- завдань в ході організації навчального процесу засвідчують значне підвищення ступеня якості засвоєння студентами навчального матеріалу та практичних навичок і умінь.

Висновки: 1. В роботі обгрунтовані методологічні основи використання тестового контролю у структурі навчальної підготовки студентів під час вивчення нормативної дисципліни "Гігієна та екологія".

2. Визначені головні прикладні напрямки застосування стандартизованих завдань тестового контролю в ході здійснення контролю рівня знань студентів.

нізації навчального процесу у вищих медичних і фармацевтичному навчальних закладах України III-IV рівнів акредитації. - Тернопіль, 2011.-С. 23-26.

4. Гігієна та екологія / [В. Г. Бардов, В. Ф. Москаленко, С. Т. Омельчук та ін.] ; за ред. В. Г. Бардова. - Вінниця : Нова Книга, 2006.-720 с.

5. Гигиена и экология / [В. Г. Бардов, В. Ф. Москаленко, С. Т. Омельчук и др.] ; под ред. В. Г. Бардова. - Вінниця : Нова Книга, 2008. - 720 с.

6. Підаєв А. В. Болонський процес в Свропі. Що таке і чи потрібний він Україні? Чи можлива інтеграція медичної освіти України в Європейський освітній простір? / А. В. Підаєв, В. Г. Передерій. - Одеса : Одес. держ. мед. ун-т, 2004.- 190 c.

7. Hygiene and ecology / [V. H. Bardov, V. F. Moskalenko, S. T. Omelchuk et al.] ; under the editorship V. G. Bardov. Vinnytsia : Nova Knyha publishers, 2009. -652 p. 